\title{
PERAN MAHASISWA PGMI IAIN KUDUS SEBAGAI AGENT OF CHANGE DI MASA PANDEMI COVID-19
}

\author{
Rochanah \\ Institut Agama Islam Negeri Kudus, Kudus, Indonesia \\ hana@stainkudus.ac.id
}

\begin{abstract}
Abstrak
The purpose of this study was to find out what roles PGMI students can play as agents of change during the COVID-19 pandemi. This type of research is a field research with a qualitative approach. In collecting data, researchers used interview techniques. In particular, the problems that the researchers raised in this study were; What is the role of students as agents of change in supporting children's learning activities during the Covid-19 pandemi? The focus of this research is in the neighborhood where the students live, namely the Pantura area, covering Kudus, Pati, Jepara, Demak. This research is a qualitative research with a descriptive-analytical method. Data collection techniques through interviews. This study resulted in a conclusion that the role of students as agents of change in the education sector during the Covid-19 pandemi includes; become a facilitator in learning activities, create fun learning, provide education about healthy lifestyles, instill adab, provide skills to children.
\end{abstract}

Keywords: Role of Student; Agent Of Change; Covid-19 Pandemic

\begin{abstract}
Abstrak
Tujuan penelitian ini adalah untuk mengetahui peran apa saja yang dapat dilakukan mahasiswa PGMI sebagai agent of change di masa pandemi Covid-19. Jenis penelitian ini merupakan penelitian lapangan dengan pendekatan kualitatif. Dalam mengumpulkan data, peneliti menggunakan Teknik awancara. Secara khusus, permasalahan yang peneliti angkat dalam penelitian ini adalah; bagaimana peran mahasiswa sebagai agen perubahan mendukung kegiatan pembelajaran anak pada masa
\end{abstract}


pandemi Covid-19? Lokus penelitian ini adalah di lingkungan tempat tinggal siswa yakni wilayah Pantura, meliputi Kudus, Pati, Jepara, Demak. Penelitian ini adalah penelitian kualitatif dengan metode deskriptif-analitis. Teknik pengumpulan data melalui wawancara. Penelitian ini menghasilkan suatu kesimpulan bahwa peran mahasiswa sebagai Agent of change dalam bidang pendidikan di masa pandemi Covid-19 meliputi; menjadi fasilitator dalam kegiatan pembelajaran, menciptakan pembelajaran yang menyenangkan, memberikan edukasi tentang pola hidup sehat, menanamkan adab, memberikan keterampilan pada anak.

Kata Kunci: Peran Mahasiswa, Agent Of Change, Pandemi Covid-19.

\section{A. Pendahuluan}

Tujuh bulan terakhir terhitung bulan Februari 2020, Indonesia telah di landa virus global atau pandemi Covid-19 yang berasal dari Wuhan, China. Sebagaimana diterangkan oleh Organisasi Kesehatan Dunia World Health Organization, Covid-19 merupakan suatu jenis penyakit yang belum pernah menjangit manusia di tahun tahun sebelumnya dan baru muncul pada tahun 2019 (Mona, 2020, hal. 117).

Di negara Indonesia, pemerintah memutuskan bahwa akibat Covid-19 ini, Indonesia berstatus darurat bencana terhitung tanggal 29 Februari 2020 hingga 29 Mei 2020. Beberapa upaya telah diputuskan oleh pemerintah dalam rangka meminimalisir bencana dunia ini, upaya dini yang dapat dilakukan yakni menghimbau masyarakat untuk menerapkan gerakan Social Distancing. Gerakan ini menghimbau pada setiap masyarakat untuk dapat menjaga jarak satu sama lain pada suatu kerumunan, dengan batas minimal 2 meter. Hal ini sebagai upaya untuk meminimalisir penyebaran virus Covid-19 (Buana, 2020).

Dengan cepatnya penyebaran virus corona, maka organisasi kesehatan dunia pada tanggal 11 Maret 2020 ditetapkan sebagai pandemi. Status pendemi ini menjelaskan bahwa virus corona 
sangatlah berbahaya dan penyebarannya sangatlah cepat karena merambah ke seluruh dunia (Mona, 2020, p. 117) Dilansir dari detik.com bahwa Negara yang terjangkit virus corona meliputi; Amerika serikat, brazil, India, Rusia, Peru, Chile, Inggris, Mexico, Spanyol, Iran, Itali, Pakistan, Arab Saudi, Turki, Prancis, Jerman, Afrika Selatan, Bangladesh, kolombia, Kanada, Qatar, China, Argentina, Mesir, Swedia, Indonesia, Belarus, Irak, dll yang jumlahnya mencapai 193 negara.

Covid-19 ini adalah salah satu virus baru yang menyerang sistem imunitas tubuh, virus ini belum di ketahui secara pasti darimana asalnya tetapi virus Covid-19 ini di duga berasal dari hewan seperti kelelawar dan kucing. Biasanya virus ini bereaksi setelah 2-14 hari setelah ada kontak dengan pengidap Covid-19. Gejala awal memang cukup sulit di bedakan dengan penyakit flu biasa, yakni demam di sertai pilek, tenggorokan kering dan apabila virus ini akut akan dapat merusak kinerja paru-paru sehingga pernafasan terganggu dan akhirnya menyebabkan kematian. Virus ini sangat berbahaya karena dapat menular melalui cairan dari mulut, telinga dan hidung si penderita, juga dapat menempel pada benda-benda mati yang telah dipegang oleh si penderita.

Hal ini sebagaimana dijelaskan dalam penelitian yang telah dilakukan oleh Nur Rohim Yunus, bahwa Coronavirus adalah sekumpulan virus dari subfamili Orthocronavirinae dalam keluarga Coronaviridae dan ordo Nidovirales. Jenis penyakit ini dapat menyerang manusia dan burung. Akibat yang ditimbulkan jika menyerang manusia yakni terjadinya infeksi pada saluran pernafasan manusia seperti flu, batuk, demam, dan gejala lain yang lebih mematikan yakni SARS, dan MERS (Yunus, 2020).

Tim medis juga tak henti-hentinya meneliti dan memperbarui vaksin untuk mematikan virus dan menghentikan penyebarannya, akan tetapi sampai sejauh ini belum di temukan vaksin yang benarbenar dapat mengatasi permasalahan virus Covid-19 tersebut. Selama ini cara penanganan masih dengan memberikan obat pereda rasa sakit si penderitanya dan percobaan baru yang akan 
di lakukan yaitu dengan tranfusi darah pasien yang sudah sembuh dari Covid-19. Cara ini belum sepenuhnya terbukti mengobati tetapi sedikit membantu proses penyembuhan pasien positif Covid-19.

Diantara dampak yang cukup dirasakan oleh putra putri bangsa akibat pandemi Covid-19 ini adalah dalam bidang Pendidikan. Pembelajaran dialihkan belajar di rumah masingmasing dengan sistem dalam jaringan atau Online (Ahsani, 2020). Sejak virus corona dinyatakan mulai merambah di negara Indonesia dan menjangkit beberapa warganya, maka pemerintah melalui Menteri Pendidikan memutuskan bahwa kegiatan pembelajaran tidak dilakukan secara tatap muka, melainkan secara online di rumah masing-massing. Keadaan demikian menimbulkan banyak keresahan, baik oleh pendidik, orang tua maupun anak didik/ siswa. Pendidik belum siap karena dalam benak mereka tidak merencanakan pembelajaran secara online dan jarak jauh. Orang tua "kewalahan" karena posisi pendidik di sekolah beralih ke orang tua. Orangtua beralih profesi sebagai "guru dadakan" sehingga harus mengarahkan, membimbing dan bahkan membantu menyelesaikan permasalahan yang dihadapi anak ketika proses pembelajaran. Tentunya banyak orang tua yang sangat tidak siap dengan aktivitas/ kesibukan yang ditekuninya. Adapun dampak yang dirasakan siswa adalah dari berbagi sudut, baik ketidakpahaman karena dipandu belajar bukan oleh guru sesungguhnya, kebosanan karena suasana yang monoton, maupun rasa malas karena lebih tertarik untuk bermain dan aktivitas lainnya.

Di tengah keresahan dan problematika yang dialami oleh berbagai pihak, banyak peran penting yang dilakukan dari berbagai elemen, salah satunya adalah peran dari mahasiswa. Dalam bidang akademik, mahasiswa menunjukkan peranan yang paling tinggi yang mengatur pola integritas manusia dari tahap remaja menuju pada peran yang sesungguhnya sebagai orang dewasa. Dengan kata lain mahasiswa adalah sebuah proses dimana mindset mengarah kepada tanggung jawab yang lebih 
besar dalam kehidupan bermasyarakat. (Nasari, 2015, p. 73) Dalam tulisan ini peneliti akan memfokuskan berbagai peran yang telah dilakukan mahasiswa PGMI IAIN Kudus. Mahasiswa Pendidikan Guru Madsarah Ibtidaiyah (PGMI) merupakan satu dari beberapa program yang ada di perguruan tinggi yang dididik untuk menghadirkan calon guru yang handal dan mumpuni untuk mengajar pada tingkat pendidikan dasar, yang berdasar pada Hukum Permendikbud No. 6 Tahun 2019 tentang Pedoman Organisasi dan Tata Kerja Satuan Pendidikan Dasar dan Menengah. Selanjutnya dijelaskan bahwa:

Pendidikan Dasar adalah jenjang pendidikan pada jalur pendidikan formal yang melandasi jenjang pendidikan menengah, yang diselenggarakan pada Satuan Pendidikan berbentuk Sekolah Dasar dan Madrasah Ibtidaiyah (MI) atau bentuk lain yang sederajat serta menjadi satu kesatuan kelanjutan pendidikan pada Satuan Pendidikan yang berbentuk sekolah menengah pertama dan madrasah tsanawiyah (MTs) atau bentuk lain yang sederajat.

Berangkat dari hal tersebut, maka penelitian ini bertujuan untuk mengetahui peran apa saja yang dapat dilakukan mahasiswa PGMI sebagai agent of change di masa pandemi Covid-19. Oleh karenanya, peran mereka sebagai calon guru MI sangat dibutuhkan dalam rangka menjaga kelangsungan pendidikan anak pada masa pandemi Covid-19 ini yang dampaknya cukup mengagetkan dunia Pendidikana. Dengan peran mereka diharapkan akan tetap menjaga kestabilan pembelajaran yang tetap terjaga kualitasnya. Hal inilah yang menjadi core value dan point pentingnya penelitian yang dilakukan ini. Adapun kontribusi yang dapat disumbangkan dalam penelitian ini yakni dapat dijadikan sebagai acuan bagi akademisi pada umumnya, dan mahasiswa prodi PGMI pada khususnya, bahwa mereka sebagai mahasiswa memiliki peran sebagai agen perubahan dalam setiap keadaan untuk menciptakan keadaan yang lebih baik, termasuk dalam masa pandemi Covid-19. 
344 | Rochanah

\section{B. Pembahasan}

\section{Metode Penelitian}

Penelitian ini merupakan penelitian lapangan (field research) dengan pendekatan deskriptif kualitatif yang bertujuan untuk bertujuan untuk mengetahui peran apa saja yang dapat dilakukan mahasiswa PGMI sebagai agent of change di masa pandemi Covid-19. Narasumber dalam penelitian ini adalah mahasiswa IAIN Kudus Fakultas Tarbiyah Prodi PGMI semester VII. Lokasi penelitian ini ada di lingkungan dimana mahasiswa menetap, yakni Kudus, Jepara, Demak, Pati.

Teknik pengumpulan data yang digunakan dalam penelitian ini adalah wawancara Terdapat lima mahasiswa prodi PGMI yang dijadikan sebagai narasumber dalam penelitian ini. Dan terdapat lim siswa dan satu orang tua siswa yang menjadi objek dari penelitian.

Teknik analisis data dalam penelitian ini menggunakan analisis kualitatif yang bersifat induktif, yaitu suatu analisis berdasarkan data yang diperoleh, selanjutnya dikembangkan pola hubungan tertentu. Adapun langkah-langkah yang harus dilalui dalam analisis data adalah reduksi data (merangkum memilih halhal yang pokok, memfokuskan pada hal-hal yang penting sesuai dengan tema) dan membuang data-data yang tidak penting. Masing-masing baris data diberi kode dengan masing-masing pertanyaan penelitian. Selanjutnya dilakukan display data, dan conclusion drawing atau verification (Sugiyono, 2010, p. 341).

\section{Hasil dan Pembahasan}

Secara umum, Pendidikan Tinggi memiliki peran, fungsi dan tujuan yang sama antara satu dengan lainnya. Peran, fungsi dan tujuan tersebut bertujuan untuk meningkatkan martabat manusia melalui transfer of knowledge dan transfer of values. Perguruan tinggi merupakan suatu lembaga yang bertujuan menghasilkan SDM yang handal dan berkualitas agar SDM tersebut dapat berkontribusi untuk mengabdikan diri di masyarakat. Mahasiswa 
sebagai insan yang mengenyam pendidikan di perguruan tinggi sangat berperan memberikan kontribusi nyata kepada masyarakat. Peran yang disandang pemuda Indonesia sebagai agen perubahan (Agent of Change) dan agen kontrol social (Agent of Social Control) sangatlah efektif dalam memposisikan peran mahasiswa untuk melakukan aksi nyata dalam masyarakat. Sebagai masyarakat, tentunya harus mengakui dan menyadari betul bahwa pendidikan merupakan kegiatan memberikan dampak perubahan terhadap kehidupan. Hal ini menjadi salah satu motivasi tersendiri bagi mahasiswa. (Sahipul Anwar, 2019, p. 180) Oleh karenanya, sebagai upaya mewujudkan perubahan tersebut, maka mahasiswa harus menunjukkan eksistensi yang nyata dalam mengabdi kepada masyarakat.

Demi meminimalisir rantai penyebaran Covid-19 dan sebagai upaya untuk tetap dapat memenuhi kebutuhan peserta didik akan layanan pendidikan, maka pemerintah pada tanggal 18 Mei 2020 melalui Kementerian Pendidikan dan Kebudayaan (Kemendikbud) mengeluarkan surat edaran nomor 4 tahun 2020. Surat Edaran tersebut berisikan tentang Pedoman tentang bagaimana proses keberlangsungan pembelajaran dari rumah di Masa Darurat Penyebaran Covid-19, sebagai berikut:

"Dalam rangka pemenuhan hak peserta didik untuk mendapatkan layanan pendidikan selama darurat penyebaran Corona Virus Disease (Covid-19) melalui penyelenggaraan Belajar dari Rumah sebagaimana tercantum dalam Surat Edaran Nomor 4 Tahun 2020 tentang Pelaksanaan Kebijakan Pendidikan da-lam Masa Darurat Penyebaran Corona Virus Disease (Covid-19), dengan hormat kami sampaikan hal-ha1 sebagai berikut: 1. Belajar dari Rumah selama darurat penyebaran Corona Virus Disease (Covid-19) dilaksanakan dengan tetap memperhatikan protokol penanganan Covid-19; dan 2. Belajar dari Rumah melalui pembelajaran jarak jauh daring dan/ atau luring dilaksanakan." (Kemendikbud, 2020)

Surat edaran yang tersebut dikeluarkan sebagai bentuk dukungan dan kepedulian pemerintah serta sebagai pedoman 
346 | Rochanah

tentang pelaksanaan kegiatan belajar dari rumah. Surat edaran tersebut dikeluarkan dengan tujuan untuk tetap dapat memberikan layanan pendidikan bagi anak dan memutus mata rantai penyebaran virus Covid-19. Berkaitan dengan hal tersebut, maka sudah selayaknya mahasiswa mendukung pemerintah dalam memberikan layanan pendidikan di masa pandemi Covid-19.

Mahasiswa merupakan sekelompok individu yang mendapatkan status sosial tertinggi dalam dunia pendidikan. Sebagai mahasiswa individu diangggap sebagai Agent of change atau cendekiawan muda dalam strata sosial yang sarat dengan berbagai predikat. Menurut Knopfemacher, mahasiswa adalah individu yang menempuh pendidiakan di erguruan tinggi untuk memperoleh gelar sarjana yang pada akhirnya akan ikut berperan untuk memajukan tatanan masyarakat. Mahasiswa dididik dan diharapkan menjadi calon-calon intelektual (Ebtanasti, 2014, p. 5).

Dalam kehidupan bermasyarakat, ada tiga peran penting yang seharusnya terpatri dalam diri mahasiswa, yakni Agent of change, social control dan iron stock Sebagaimana dijelaskan dalam penelitian yang dilakukan oleh Ilmaa Surya Istichomaharani, Sandra Sausan Habibah dengan judul Mewujudkan Peran Mahasiswa Sebagai "Agent of change, Social Control, Dan Iron stock" bahwa peran mahasiswa sebagai Agentof change, maka mahasiswa dituntut untuk mendayagunakan tenaga dan fikirannya dalam rangka mengadakan suatu perubahan menuju keadaan yang lebih baik di kehidupan masyarakat. Artinya, mahasiswa harus action dan bukan hanya berpangku tangan manakala melihat keadaan yang meresahkan dalam suatu masyarakat. Sebagai social control, maka peran mahasiswa adalah sebagai pengontrol kebijakan pemerintah yakni pengontrol aturan dan kebijakan yang dikeluarkan pemerintah. Dalam hal ini, maka mahasiswa harus memiliki sikap jeli dan kritis terhadap setiap kebijakan yang diputuskan pemerintah karena berkaitan langsung dengan khalayak umat. Sebagai iron stock, mahasiswa diharapkan menjadi generasi penerus bangsa yang tangguh dan memiliki moral yang 
baik. Sikap Tangguh yang dimiliki mahasiswa harus ditunjukkan dalam setiap keadaan, memiliki semangat juang yang tinggi dan pantang menyerah (Istichomaharani, 2016).

Mahasiswa selayaknya memiliki pandangan jauh ke depan akan tatanan kehidupan yang lebih baik untuk dirinya sendiri maupun bagi khalayak masyarakat, khususnya masyarakat dimana ia tinggal. Sebagai perwujudan dari peran mahasiswa sebagai agent of change, maka mahasiswa dapat melakukan aksi nyata sebagai problem solver atas berbagai persoalan yang dialami masyarakat. Sebagai Agent of change mahasiswa harus menghadirkan adanya pergeseran pada keadaan yang lebih baik dalam kehidupan bermasyarakat.

Menghadapi situasi pendidikan yang memprihatinkan akibat pandemi Covid-19, maka peran mahasiswa sebagai agent of change yang melekat dalam diri mahasiswa harus benar-benar diimplementasikan dalam kehidupan masyarakat. Mahasiswa sebagai Agent of change adalah orang-orangyang bertindaksebagai katalis atau pemicu terjadinya suatu perubahan yang bisa bisa saja menimbulkan dampak positif maupun negative. Perubahan merupakan hal yang wajib terjadi agar menghasilkan bangsa yang besar, kuat sejahtera lahir dan bathin serta bermartabat di mata dunia. Mahasiswa sebagai sekumpulan orang terdidik yang berasal dari berbagai disiplin ilmu akan menjadi suatu kekuatan sosial yang sangat luar biasa dalam melakukan berbagai perubahan. Namun demikian, sebagai manusia yang terdidik, harapan yang diinginkan masyarakat tentunya adalah menimbulkan dampak positif, bukan negative.

Mahasiswa menjadi asset milik bangsa karena Pendidikan yang diperolehnya dalam bidang keilmuan dan keterampilan. Oleh karenanya, melihat kondisi masyarakat yang semakin kompleks akibat perkembangan zaman yang tidak menentu, maka peran mahasiswa sebagai Agent of change harus mampu menghadapi berbagai tantangan yang ditimbulkan akibat pergeseran zaman itu sendiri dengan segala problematikanya. Sebagai Agent of 
change, maka mahasiswa harus menjadi sosok yang hidup di masa saat ini, yakni harus melek iptek dan peduli terhadap lingkungan sekitar dimana ia tinggal. Dengan memahami hal tersebut, maka mahasiswa akan menyadari berbagai permasalahan yang menimpa lingkungan sekitarnya. Hal ini karena untuk dapat mengusung dan menghadirkan suatu perubahan, hanya akan nampak pada mahasiswa yang sadar akan keadaan. Oleh karenanya, sebagai agen perubahan maka mahasiswa harus sadar dan peduli akan keadaan yang menimpa dunia saat ini, yakni pandemi virus corona.

Wujud nyata peran mahasiswa sebagai Agent of change adalah memberikan pelayanan kepada masyarakat atas perubahan zaman sebagai dampak dari penyebaran virus corona. Dalam hal ini, dampak dari virus corona sangat dirasakan oleh anak-anak yang sedang mengenyam pendidikan, baik pendidikan tingkat dasar maupun pendidikan menengah. Hal ini karena secara mendadak, pemerintah memutuskan bahwa pembelajaran harus dilaksanakan secara daring/ online sebagai upaya untuk menghentikan berkembangnya virus Covid-19. Oleh karenanya, mahasiswa harus berperan aktif dalam rangka mendukung program pemerintah agar dapat berjalan dengan semestinya.

Mahasiswa sebagai insan akademis, diyakni berkekuatan dalam hal intelektual yang lebih tinggi daripada mereka yang tidak menyandang gelar sebagai mahasiswa. Berkenaan dengan hal tersebut, maka mahasiswa diharapkan memiliki nalar yang solutif dan sikap kepekaan yang tinggi sehingga mampu memberikan sumbangsih yang berharga bagi masyarakat yang ada di lingkungannya, terutama dalam bidang pendidikan dan sosial masyarakat. Maka dari itu peran mereka sangat dibutuhkan dalam masyarakat. Sebagai mahasiswa PGMI, hal tersebut menjadi tantangan besar bagi mereka. Bagaimana cara untuk tetap mempertahankan kegiatan pembelajaran bagi anak tingkat SD/ MI pada masa pandemi Covid-19. Mengingat bahwa anak ditingkat SD/MI masih membutuhkan bimbingan yang lebih dibanding 
tingkat atasnya. Peran mahasiswa PGMI dalam meningkatkan kualitas pendidikan anak tingkat SD/MI pada masa pandemi Covid-19 yaitu dengan memperbaiki kualitas pembelajaran itu sendiri. Hal ini mengingat dimasa pandemi Covid-19 aktivitas pembelajaran menjadi terganggu. Tidak hanya peserta didik saja yang terkena imbasnya, namun pendidik juga merasakan dampak yang sama dalam menjalankan aktivitas pembelajaran. Para pendidik harus berputar otak agar dapat memberikan pelajaran, wawasan dan pengetahuan yang mudah dicerna siswa, walaupun tidak bertatap muka secara langsung. Sehingga peserta didik dapat maksimal belajar ditengah pandemi Covid-19.

Menurut Siti Nur Azizah, dalam meningkatkan kualitas pendidikan anak tingkat SD/MI pada masa pandemi Covid-19 maka langkah pertama yang harus disadari adalah memulai dari diri sendiri yakni mengembangkan potensi diri sebagai bentuk kesadaran akan hakikat pendidikan yang mendasar. Dalam hal ini, maka sebagai seorang yang sedang menyandang gelar "maha"siswa harus mempunyai kesadaran yang mendalam bahwa ia dan sejuta "maha"siswa yang lain, perannya sangat dibutuhkan di masyarakat. Kemudian, langkah selanjutnya adalah melakukan kontrol atas kebijakan pemerintah dalam bidang Pendidikan.

Beberapa peran yang dilakukan mahasiswa prodi PGMI untuk meningkatkan kualitas pembelajaran di masa pandemi Covid-19.

Pertama, menjadi fasilitator dalam kegiatan pembelajaran. Berdasarkan hasil wawancara dengan Siti Nur Azizah yang saat ini berstatus sebagai mahasiswa prodi PGMI IAIN Kudus semester VI, menurutnya, perannya sebagai mahasiswa PGMI menjadi fasilitator dalam kegiatan pembelajaran anak di lingkungan tempat tinggalnya. Sebagai fasilitator, maka peran yang dilakukannya adalah mengidentifikasi kebutuhan siswa dengan memnafaatkan berbagai refernsi, baik yang bisa didapatkan secara cetak maupun secara online melalui jaringan internet. 
Seiring perkembangan zaman, kemajuan teknologi semakin canggih sehingga hampir semua kalangan memanfaatkan fasilitas ini untuk berbagai kebutuhan, baik oleh kalangan tua maupun muda, dalam hal ini anak yang mengenyam pendidikan dasar pun sudah dapat memanfaatkan fasilitas internet. Melalui internet berbagai kemudahan yang didapatkan untuk pemenuhan kebutuhan bersosialisasi, mencari informasi dari berbagai belahan dunia, untuk kebutuhan hiburan, termasuk untuk mencari informasi terkait pembelajaran. Namun demikian, dalam hal penggunaan fasilitas internet ini, banyak sisi positif dan sisi negatif yang akan di dapat. Dalam penggunaannya, maka diharuskan adanya pendampingan pada anak. Hal ini sebagai upaya meminimalisir pemanfaatan fasilitas internet yang tidak bertanggung jawab. Hal ini mengingat banyak informasi negatif yang sewaktu waktu dapat muncul dalam beranda, maupun yang dengan mudah didapatkan, seperti situs pornografi, game online yang mengakibatkan kecanduan, peyadapan data data berharga, transaksi jual beli narkoba, terorisme, penipuan, dan situs lain yang dirasa merugikan generasi penerus bangsa (Hakim, 2017, p. 281). Oleh karena itu, maka sudah selayaknya anak tidak dibebaskan dalam penggunaan fasilitas ini, sehingga memutuhkan pendampingan.

Sebagaimana dijelaskan dalam penelitian Mega rahmawati, bahwa sebagai upaya menciptakan keefektifan dalam kegiatan pembelajaran, maka peran guru diantaranya adalah sebagai sumber informasi, pemberi nasihat dan ilmu pengetahuan. Adapun indikator variabel peran guru sebagai fasilitator terdiri dari 3 ukuran yaitu; 1) tindakan guru untuk membantu siswa dalam pembelajaran dengan menunjukkan perilaku yang baik 2) memahami peserta didik dalam kegiatan pembelajarn 3) memiliki kemampuan dan kepedulian akan berbagai perbedaan yang ada dalam diri peserta didik (Rahmawati, 2019, p. 51).

Disaat pandemi covid'19, sistem pembelajaran mengalami perubahan secara drastis yang menjadikan tantangan bagi pendidik dan peserta didik untuk tetap dapat mempertahankan 
kegiatan pembelajaran, meskipun tidak bisa dilakukan secara tatap muka seperti sebelum adanya Covid-19, namun pelayanan pendidikan harus tetap diberikan. Dalam hal ini, pada realitanya bukan hanya peserta didik semata yang merasakan kesulitan dalam melangsungkan proses pembelajaran, namun sejatinya pendidik jauh lebih kesulitan. Hal ini karena mereka harus memutar otak mencari cara yang tepat dengan berbagai alternative media pembelajaran berbasis online untuk menunjang proses pembelajaran yang dituntut serba digital. Meskipun demikian, kesiapan harus dituntut oleh semua pihak, baik oleh guru maupun oleh siswa. Walaupun di dunia pendidikan hal ini bukanlah suatu hal yang baru, namun dipastikan masih banyak pendidik dan peserta didik yang awam dan kesulitan dalam mengaplikasikannya.

Menanggapi hal tersebut, maka peran yang dapat dilakukan Siti Nur Azizah untuk meminimalisir ketimpangan yang dialami oleh anak didik adalah dengan membantu menjelaskan ulang materi yang belum dipahami oleh anak yang dipandunya. Hasil wawancara dengan Rahma Aulia, salah satu murid kelas IV MIN di kabupaten Kebumen diperoleh keterangan bahwa pembelajaran secara online di masa pandemi dirasakan sangat membosankan karena selalu monoton dengan Handphone. Penjelasan hanya diberikan secara singkat melalui video WA. Tindakan yang dapat dilakukannya ketika menemui kesulitan dalam mengerjakan tugas yang diberikan oleh guru adalah bertanya kepada orangtuanya. Adapun jika karena suatu keadaan orang tua tidak bisa membantunya, maka jalan satu-satunya adalah dengan browsing di internet. Berpijak dari keadaan tersebut maka orangtua harus memberikan pendampingan pada anak dalam proses belajar. kegiatan belajar siswa dilaksanakan di rumah dengan bimbingan dari orang orang tua (Ahsani, 2020). Artinya, anak tetap harus dilibatkan dalam proses pembelajaran dalam kegiatan sekecil apapun. Sebagaimana dijelaskan dalam penelitian yang dilakukan peneliti di artikel sebelumnya bahwa agar tercapai tujuan 
pembelajaran yang efektif, maka anak harus dilibatkan secara langsung dalam aktivitas pembelajaran (Rochanah, 2019, p. 32).

Sebagaimana yang dijelaskan oleh Ayu Lestari Nengrum bahwa, dalam upaya membantu kesulitan belajar yang dialami anak, maka ia mencoba memberikan penjelasan ulang yang mudah dipahami dan dapat dicerna oleh anak, sehingga mereka tidak kesulitan dalam belajar dan tidak merasa tertekan jika belajar di rumah. Hal tersebut tentunya akan dapat meringankan dan membantu mereka dalam belajar.

Hal ini pun juga dijelaskan oleh Dewi Susana, sebagai motivator ia memberikan semangat kepada anak-anak meskipun pembelajaran tidak bisa dilakukan secara tatap muka. Ia juga berpesan kepada anak-anak untuk tidak pantang menyerah atas keadaan yang sedang terjadi saat ini. Dengan adanya semangat yang diberikan, anak pun akan memiliki semangat yang tinggi untuk tetap belajar di rumah dengan segala keterbatasan yang ada.

Sebagaimana dijelaskan dalam M. Dalyono bahwa, dalam kegiatan apapun dibutuhkan adanya tenaga penggerak atau pendorong dalam diri, baik yang berasal dari dirinya sendiri maupun orang lain. Hal ini dilakukan untuk menumbuhkan semangat yang tinggi agar pekerjaan yang dilakukan mudah terselesaikan. Maka dalam kegiatan pembelajaran pun berlaku demikian. Pembelajaran yang dilakukan dengan adanya motivasi yang tinggi, maka kegiatan belajar dilakukan dengan sungguhsungguh dan penuh semangat. Sebaliknya, tanpa adanya motivasi belajar, maka kegiatan belajar cenderung menyebabkan sikap malas dan tanpa kesungguhan (Dalyono, 2001, p. 57).

Untuk mencapai hasil belajar yang memuaskan, maka diperlukan adanya pendorong, baik yang datang dari diri sendiri, yakni individu yang bersangkutan maupun dari luar. Hal ini karena motivasi merupakan suatu tenaga penggerak agar seseorang mampu bertindak dalam upaya mencapai hasil yang diharapkan, termasuk dalam mewujudkan hasil belajar yang optimal. Oleh karenanya, motivasi belajar sangatlah penting dalam proses 
pembelajaran. Tugas sebagai pendidik adalah mengarahkan agar setiap anak didik memiliki motivasi yang kuat dalam belajar, sehingga hasil yang dicapai tidak mengecewakan.

Kedua, menciptakan pembelajaran yang menyenangkan. Dalam kegiatan pembelajaran selayaknya dilaksanakan dengan suasana yang menyenangkan. Pembelajaran yang menyenangkan diharapkan oleh semua anak didik. Pembelajaran dikatakan menyenangkan manakala di dalamnya terdapat suasana yang rileks, anak terbebas dari tekanan dan ancaman sehingga akan hadir rasa aman, dan nyaman dalam diri anak. Hal ini lah yang dirindukan oleh anak. Dengan hadirnya rasa tersebut, maka anak akan mudah menerima pembelajaran, sehingga kegiatan pembelajaran membuahkan hasil. Adapun pembelajaran yang menimbulkan ketakutan, rasa was-was, cemas dan menegangkan merupakan pembelajaran yang tidak menyenangkan bagi anak. Dengan keadaan tersebut, anak hanya akan merasa terbebani dalam belajar (Indrawati, 2009, p. 24). Hal ini diperkuat oleh pendapat La Iru dan La Ode Safiun Arihi bahwa untukmenghasilkan pembelajaran yang efektif, maka suasana pembelajaran yang menyenangkan harus diciptakan oleh guru (Iru, 2012, pp. 98-99).

Salah satu upaya untuk menciptakan pembelajaran yang menyenangkan sebagaimana diungkapkan oleh Siti Nur Azizah adalah membuat video edukasi. Menurut Siti Nur Azizah, membuat video edukasi adalah salah satu cara menjadikan kegiatan pembelajaran tidak membosankan bagi anak didik. Anak tingkat SD/MI yang notabennya masih suka bermain dan memiliki rasa ingin tahu yang tinggi, sangat mudah merasakan kebosanan dengan suasana monoton. Jika pendidik hanya menyampaikan materi dengan cara yang kurang menarik, maka dampak yang ditimbulkan anak cenderung akan bosan dengan pembelajaran tersebut dan menjadikan anak malas dalam belajar. Sebagai mahasiswa, ia ikut mengabdikan diri dan berperan dalam menyumbangkan inovasi dalam proses pembelajaran, yakni membuat video edukasi untuk mendukung mata pelajaran pada 
tingkat SD/MI. Dengan demikian, anak akan lebih tertarik dan mudah memahami materi yang disampaikan.

Adapun menurut Dewi, untuk mempermudah pemahaman anak akan materi yang diterimanya dari sekolah, maka ia mengajarkan untuk gemar membaca, yakni dengan mminjaminya buku anak atau buku pengetahuan bergambar Dalam hal ini, anak diasah kreativitasnya dengan menggambar, mengekspresikan apa yang sedang dialaminya lewat gambar.

Upaya lain untuk menciptakan pembelajaran yang menyenangkan adalah dengan bantuan. Untuk menciptakan pembelajaran yang menyenangkan, maka perlu adanya perencanaan yang matang. Hal ini karena pembelajaran yang menyenangkan tidak serta merta terjadi dengan sendirinya tanpa adanya suatu perencanaan. Diantara upaya untuk menghadirkan suasana yang menyenangkan adalah melibatkan media pembelajaran untuk mempermudah pemahaman siswa dalam belajar (Uno, 2011, p. 10).

Dalam penelitian yang dilakukan oleh Ardian Asyhari menjelaskan bahwa, Media pembelajaran dimaknai sebagai apapun yang dapat digunakan untuk menyampaikan pesan, merangsang pikiran, kemauan danperhatian peserta didik sehingga dapat menggerakannya untuk berproses dalam kegiatan belajar. Media pembelajaran digunakan agar kegiatan pembelajaran dapat dirasakan lebih konkret. Dalam hal ini Gagne dan Briggs menekankan pentingnya media pembelajaran sebagai alat untuk merangsang proses belajar. Dapat disimpulkan bahwa media pembelajaran merupakan alat apapun yang dapat memudahkan dan memahamkan anak dalam menerimaan pesan pembelajaran/ materi yang diterima dari guru (Asyhari, 2016, p. 3).

Diantara media yang dapat digunakan untuk menciptakan pembelajaran yang menyenangkan adalah dengan media ular tangga untuk mendukung pembelajaran matematika. Melalui permainan ular tangga, rasa jenuh dalam diri anak akan terhindarkan. Hal ini karena selain dapat mengasah otak anak dalam bidang matematika, anak juga dapat belajar sambil 
bermain. Sebagaimana diungkapkan oleh Dewi bahwa, media yang digunakan untuk menunjang kegiatan pembelajaran agar terasa menyenangkan adalah dengan membuat jaring-jaring kubus, balok dan lain-lain.

Ketiga, memberikan edukasi tentang pola hidup sehat. Menurut Siti Nur Azizah, ia merancang pembelajaran onsite bagi anak dilingkup terdekat baik indoor maupun outdoor dengan tetap mematuhi protokol kesehatan yang telah di tetapkan. Seperti mencontohkan bagaimana pola hidup sehat, selalu menjaga jarak di tempat keramaian, mengenakan masker saat keluar rumah, rajin mencuci tangan dan lain sebagainya.

Sebagaimana yang dijelaskan oleh Ayu Lestari Nengrum bahwa, peran yang dilakukannya saat pandemi Covid-19 dalam meningkatkan kualitas pendidikan anak di sekitar tempat tinggalnya yakni dengan memberikan edukasi kepada anak-anak disekitar rumah mengenai apa itu Covid-19 dan bagaimana pencegahanya sesuai dengan pemahaman anakanak. Dalam memberikan penjelasan, ia mengaitkannya dengan materi pembelajaran misalnya tentang kebersihan. Di dalam pembelajarannya dapat disisipkan bagaimana cara mencucitangan yang baik dan benar sehingga anak-anak tidak hanya dituntut dengan materi saja tetapi mereka juga bisa mempraktikanya secara langsung, sesuai dengan protokol kesehatan. Hal ini pun diungkapkan oleh Hasyim Asnawi, dalam masa pandemi Covid-19 ini, anak diajarkan bagaimana bagaimana etika bersin, cara memakai masker yang benar dan cara mencuci tangan yang benar untuk menjaga kebersihan. Sebagaimana dikuatkan oleh Dewi bahwa, dalam praktisnya, sebagai upaya mewujudkan hidup bersih dan sehat, anak senantiasa diajarkan menjaga kebersihan dengan membiasakan berwudlu. Selain itu, menurut Dewi, dalam masa pandemi Covid-19 ini, anak dapat diajarkan bagaimana tata cara sholat berjamaah dengan mematuhi protokol kesehatan, yakni dengan memberi jarak antar jamaah kurang lebih satu meter ketika menjalankan ibadah shalat. 
356 | Rochanah

Keempat, menanamkan adab. Menurut Siti Nur Azizah, dari segi karakteristik dan akademik dapat mencontohkan adab, etika, sopan santun yang baik. Sebagaimana yang dijelaskan oleh Ayu Lestari Nengrum bahwa, disamping memberikan materi pembelajaran, dan motivasi, dukungan moril juga diperlukan agar mereka tetap semangat dalam belajar.

Kelima, memberikan keterampilan pada anak. Keterampilan diberikan dengan tujuan agar mereka tidak bosan selama belajar berada di rumah, salah satu keterampilan yang dapat diberikan kepadaanakmisalnya membuat masker sendiri. Pada masa pandemi Covid-19 ini, pemerintah dan tenaga kesehatan sangat menghimbau kepada semua khalayak untuk mengenakan masker ketika hendak keluar rumah, ketika dalam kerumunan dan ketika batuk/ bersin. Hal ini adalah sebagai suatu upaya untuk meminimalisir penyebaran mata rantai Covid-19. Dengan melibatkan anak untuk membuat masker maka keterampilan anak juga terasah. Mereka juga tidak hanya belajar tentang cara membuatnya saja tetapi juga materi pelajaran matematika akan bersinggungan didalamnya, yakni mengenai ukuran panjang dan lebarnya.

\section{Simpulan}

Peran mahasiswa sebagai Agent of change dalam bidang pendidikan di masa pandemi Covid-19 meliputi; menjadi fasilitator dalam kegiatan pembelajaran, menciptakan pembelajaran yang menyenangkan, memberikan edukasi tentang pola hidup sehat, menanamkan adab, memberikan keterampilan pada anak. Melalui penelitian ini, penulisa merekomendasikan beberapa hal, yakni; pertama, mahasiswa lebih maksimal dalam mengabdikan diri pada masyarakat, tidak hanya terbatas pada masa pandemi Covid-19 saja tapi pada setiap kesempatan. Hal ini dimaksudkan untuk melatih kepekaan mahasiswa pada setiap hal yang terjadi di masyarakat. Kedua, hendaknya masyarakat memberikan apresiasi nyata atas berbagai peran yang telah ditunjukkan mahasiswa, khususnya peran mahasiswa sebagai agent of change dalam bidang Pendidikan. 


\section{DAFTAR PUSTAKA}

Ahsani, Eva Luthfi Fakhru. 2020. "Strategi Orang Tua Dalam Mengajar Dan Mendidik Anak Dalam Pembelajaran At The Home Masa Pandemi Covid-19." Al Athfal: Jurnal Kajian Perkembangan Anak dan Manajemen Pendidikan Usia Dini 3(1): 37-46.

Asyhari, A. (2016). Pengembangan Media Pembelajaran Berupa Buletin Dalam Bentuk Buku Saku Untuk Pembelajaran IPA Terpadu. Al-BiRuNi: Jurnal Ilmiah Pendidikan Fisika.

Buana, D. R. (2020). Analisis Perilaku Masyarakat Indonesia dalam Menghadapi Pandemi Covid 19 dan Kiat Menjaga Kesejahteraan Jiwa. Salam: Jurnal Sosial dan Budaya Syar'i., 218.

Dalyono, M. (2001). Psikologi Pendidikan: Komponen MKDK. Jakarta: Rineka Cipta.

Ebtanasti, D. F. (2014). Survei Pilihan Karir Mahasiswa Fakultas Matematika Dan Ilmu Pengetahuan Alam Universitas Negeri Surabaya. Jurnal BK, - .

Hakim, S. N. (2017). Dampak kecanduan internet (internet addiction) pada remaja PROSIDING TEMU ILMIAH X IKATAN PSIKOLOGI PERKEMBANGAN INDONESIA Peran Psikologi Perkembangan dalam Penumbuhan Humanitas pada Era Digital. 281.

Indrawati. (2009). Modul Pembelajaran Aktif, Kreatif, Efektif, dan Menyenangkan.

Iru, L. (2012). Analisis Penerapan Pendekatan, Metode, Strategi dan Model-model Pembelajaran. Yogyakarta: Multi Presindo.

Istichomaharani, I. S. (2016). "Pengintegrasian Nilai Karakter dalam Pembelajaran Kreatif di Era Masyarakat Ekonomi Asean" Mewujudkan Peran Mahasiswa Sebagai "Agent of Change, Social Control, Dan Iron stock" Stiba Satya Widya Sura. Prosiding Seminar Nasional dan Call for Paper ke-2 . Surabaya: STIBA Satya Widya Surabaya. 
358 | Rochanah

Kemendikbud. (2020). Surat Edaran nomor 4 tahun 2020. Jakarta: Kemendikbud.

Mona, N. (2020). Konsep Isolasi Dalam Jaringan Sosial Untuk Meminimalisasi Efek Contagious (Kasus Penyebaran Virus Corona Di Indonesia) .Jurnal Sosial Humaniora Terapan., 117.

Nasari, F. (2015). Penerapan K-Means Clustering Pada Penerimaan Mahasiswa Baru (Studi Kasus Universitas Potensi Utama). Seminar Nasional Teknologi Informasi dan Multimedia , (p. 73).

Rahmawati, M. (2019). Guru sebagai Fasilitator dan Efektivitas Belajar Siswa. Jurnal Pendidikan Manajemen Perkantoran, 51.

Rochanah. (2019). Meningkatkan Kecintaan Anak pada Al Quran melalui Kebun Qur'an (Studi Kasus di Pondok Pesantren Enterpreneur al Mawaddah). Elementary: Islamic Teacher Journal, 332.

Sahipul Anwar, S. K. (2019). Peran Mahasiswa Perguruan Tinggi Islam Aceh Tenggara sebagai Agents of Social Change. ANTHROPOS: Jurnal Antropologi Sosial dan Budaya, 180.

Sugiyono. (2010). Metode Penelitian Pendidikan Pendekatan Kuantitatif, kualitatif, dan R\&D. Alfabeta. Alfabeta.

Uno, H. B. (2011). Belajar Dengan Pendekatan PAIKEM. Jakarta: PT. Bumi Aksara.

Yunus, N. R. (2020). Kebijakan Pemberlakuan Lock Down Sebagai Antisipasi Penyebaran Corona Virus Covid-19. Salam: Jurnal Sosial dan Budaya Syar'i. 